\title{
$\mathrm{Ni}$ 基合金 HR6W のクリープおよびクリープ疲労条件下の 損傷過程と EBSD 方位差測定 ${ }^{\dagger}$
}

\author{
宮本 健太* 緒方 隆志**

\section{Damage Process and Measurement of Crystal Misorientation by EBSD under Creep and Creep Fatigue Conditions on Ni Base Alloy HR6W}

by

\author{
Kenta Miунмото*and Takashi OGata**
}

Nickel based alloy HR6W is one of candidate materials for high-temperature components in an advanced ultra-super critical power plant in Japan. In application to piping, it is necessary to clarify progress of damage and life property under creep and creep-fatigue loading conditions. In this study, fatigue, creep and creep-fatigue with up to 24 hours strain hold time per cycle tests were performed on $\mathrm{HR} 6 \mathrm{~W}$ at $750^{\circ} \mathrm{C}$, and damaged specimens were produced by interrupting the tests. Cyclic failure life with 1 hour hold time reduced to about $1 / 5$ of the fatigue life, and reduction of the failure life increases with increasing the hold time due to accumulation of intergranular creep damage. Failure lives of the creep-fatigue tests were predicted by using the ductility exhaustion method. Creep voids were observed at lower damaged specimens both under creep and creep-fatigue loading, and lengths of the voids increase with increasing the damage resulting in formation of micro cracks at higher damage. For the creep and creep-fatigue damaged specimens, crystal misorientation represented by such as KAM (Kernel Average Misorientation) and GROD (Grain Reference Orientation Deviation) values were measured by using EBSD (Electron Backscatter Diffraction) analysis. KAM average values increase with the damage monotonously, in which the difference between the creep and the creep-fatigue tests was not clearly seen. On the other hand, GROD average values of the creep damage specimens is larger than those of the creep-fatigue damage specimens at the same damage indicating that creep and creep-damage of the HR6W may be detected by measuring GROD average.

\section{Key words}

HR6W, Creep, Creep fatigue, Void and micro crack, EBSD, Crystal misorientation

\section{1 緒 言}

火力発電所の効率向上による二酸化炭素排出量の削減を 目指して，蒸気温度，圧力をさらに上昇させた先進超々臨 界圧火力発電設備の開発に向けた研究が進められている 1)。蒸気温度の上昇により，現在主蒸気配管等に使用され ているフェライト系合金鋼の適用が困難となるため, さら に高温強度に優れたニッケル基合金の適用が検討されてい る. その代表材料としてラーベス層により析出強化された ニッケル基合金 HR6W が挙げられる ${ }^{2)}$. フェライト系合 金鋼配管において既に報告されているように，蒸気配管等 の高温機器では長期間使用中に高温疲労やクリープ損傷が 進行することにより，巨視き裂の発生に至ることが懸念さ れる ${ }^{3)}$. 従って，HR6W の配管等への適用にあたっては， 高温条件下での損傷の進行過程や寿命特性について明確に することが必要となる。

仙波ら ${ }^{2)}$ は，HR6W のクリープ試験の結果，同合金が優 れたクリープ破断強度を有し, 組織の安定性にも優れるこ とから Ni 基合金である Alloy617 に比べてクリープ破断延

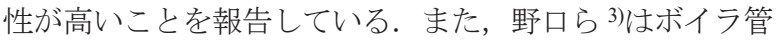

として使用寸る場合に起動-定格-停止運転中に受ける負荷 を考慮して，クリープ疲労条件下の寿命特性を把握するこ との必要性から，ひずみ波形の異なるクリープ疲労試験を 実施し，Alloy617 に比べ寿命が長いことを示した. しかし ながら，実機で使用される場合に重要となる，クリープ条 件下での損傷過程やクリープ疲労条件下での寿命に及ぼす ひずみ保持時間の影響は明らかになっていない.

一方，これまでに適用されてきたクリープ損傷の非破壊 的検出法であるボイド観察法等に加え, 金属材料の電子線 後方散乱回折(EBSD)測定から得られる結晶方位差変化と 損傷との関係を調べる研究も進められている ${ }^{4)-6) . ~ フ ェ ラ ~}$ イト系合金4)やオーステナイト系ステンレス鋼5)を対象と した研究では, クリープ損傷の増加に伴い局所方位差や結 晶粒内方位差が増大寸ることから，損傷評価の指標となる 可能性が示唆されている。また，Ni 基超合金である

Hastelloy X のクリープひずみと局所方位差との関係に相関 があること7)や一方向凝固合金のクリープ条件下のき裂開

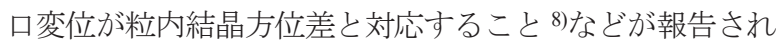
ている．このような結果を踏まえ，本 $\mathrm{Ni}$ 基合金がクリー

$\dagger$ 原稿受理 平成30年 11月 29日 Received Nov.29, 2018 @2019 The Society of Materials Science, Japan

* 千葉工業大学 大学院 $\bar{\top} 275-0016$ 習志野市津田沼

Faculty of Engineering,. Chiba Inst. of Tech., Tsudanuma, Narashino, 275-0016.

** 正 会 員 千葉工業大学 工学部 $\bar{\top} 275-0016$ 習志野市津田沼

Faculty of Engineering,. Chiba Inst. of Tech., Tsudanuma, Narashino, 275-0016. 
プあるいはクリープ疲労損傷を受ける場合の損傷と結晶方 位差パラメータとの関係を明らかにすることは，微小なサ ンプルによる損傷評価法の検討という観点から有益であ る.

本研究では, Ni 基合金 HR6W を対象にクリープ, 疲労 および長時間のひずみ保持のあるひずみ制御クリープ疲労 試験を実施し，高温強度特性を明らかにするとともに損傷 過程の解明と結晶方位差パラメータの損傷検出への適用性 について検討する.

\section{2 試験およびEBSD計測方法}

2.1 供試材料および試験方法

供試材は，研究用素材として製造された Ni 基合金 HR6W(45Ni-23Cr-7W)であり, 平均結晶粒径は約 $260 \mu \mathrm{m}$ で ある．同合金を，直径 $6 \mathrm{~mm}$, 標点距離 $30 \mathrm{~mm}$ のつば付中実 丸棒試験片に加工後，クリープ試験に供した。 クリープ試 験は，最大荷重 $30 \mathrm{kN}$ ，最高使用温度 $1100^{\circ} \mathrm{C}$ のレバー式単

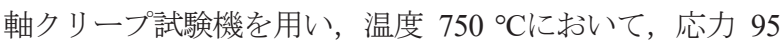
MPa および $105 \mathrm{MPa}$ の 2 条件で破断まで実施した。また, 各条件においてクリープ試験を破断前に中断して，クリー プ損傷材を作製した．クリープ損傷率は，（中断時クリー プひずみ／破断ひずみ） × 100(\%)として定義した.

次に, 直径 $6 \mathrm{~mm}$, 標点距離 $10 \mathrm{~mm}$ の中実丸棒試験片を用 い, 最大荷重 $98 \mathrm{kN}$, 最高使用温度 $1000^{\circ} \mathrm{C}$ の高周波誘導加 熱式油圧サ一ボ疲労試験機により，温度 $750^{\circ} \mathrm{C}$ に疲労お よびクリープ疲労試験を実施した。疲労試験は，対称三角 波ひずみ制御とし，ひずみ範囲 $0.5 \%, 0.7 \%, 1.0 \%$ の 3 条件 で，クリープ疲労試験はひずみ範囲を $0.7 \%$ とし，最大引張 ひずみにおいて 1 時間(1h)，5 時間(5h)および 24 時間(24h) それぞれのひずみ保持のある台形波で実施した。両試験で の引張および圧縮工程でのひずみ速度は $0.1 \% / \mathrm{sec}$ とした. 破損寿命は，引張側最大応力がほぼ一定となる疲労寿命中 期における值の $75 \%$ に低下した時点の繰返し数とした。ま た， $1 \mathrm{~h}$ および $5 \mathrm{~h}$ ひずみ保持クリープ疲労試験条件におい て，（中断繰返し数／破損寿命） $\times 100(\%)$ をクリプ疲労 損傷率と定義し，1h 保持条件においては損傷率が 40\%, 60\%，80\%となる損傷材を，5h 保持条件においては損傷率 が 25\%，50\%，75\%となる損傷材を作製した.

クリープおよびクリープ疲労損傷材は，損傷状態を把握 するため標点内平行部中央の軸方向断面（縦断面）を切断 してアクリル樹脂に埋め込み，表面を耐水研磨紙 400 番か ら 2000 番めで順次研磨し，さらに粒径 $3 \mu \mathrm{m}, 1 \mu \mathrm{m}, 0.05 \mu \mathrm{m}$ のアルミナ粉を含むアルミナ懸濁液によるバフ研磨で鏡面 に仕上げた。その後，腐食液（塩酸 : 硝酸=1 : 1）を用い て表面を腐食し, 縦断面を走査型電子顕微鏡(SEM)により 観察した。

\subsection{EBSD による方位差測定方法}

結晶方位測定・解析は, SEM に取り付けられた TSL 社 製 EBSD システム(OIM7.3)を用いて行った．測定を行う面 は，前述した耐水研磨紙による粗研磨とアルミナ懸濁液に
よるバフ研磨を実施後, 10 分間のコロイダルシリカ研磨に て最終仕上げを施した。測定は加速電圧 $15 \mathrm{kV}, \mathrm{WD}=17$ $22 \mathrm{~mm}$ で実施し, 測定領域は横 (応力垂直) 方向に $0.9 \mathrm{~mm}$, 縦（応力）方向に $2.7 \mathrm{~mm}$, ステップサイズは $3 \mu \mathrm{m}$, 結晶粒 界として認識する方位差の最低值は $5^{\circ}$ とした．測定箇所は 試験片中央部である，測定後, 結晶方位の計算結果の確か らしさを示す指標である方位同定確度を算出し, 材料学会 から出版されている測定標準 ${ }^{9} に$ 照らして, 測定が十分に 正確に行われたことを確認した。本研究では，方位差パラ メータとして KAM(Kernel Average Misorientation)および GROD(Grain Reference Orientation Deviation)を算出し ${ }^{9)}$ ，損 傷との相関を調べた. KAM は，ある結晶粒内にある測定点 について, 同一結晶粒内における全隣接測定点 (最大 6 点) との方位差を平均化した值である. また, GROD は, 結晶 粒の平均方位を基準方位とし, 同一粒内の各測定点と基準 方位との方位差を示したものである.

\section{3 試験結果および考察}

3.1 クリープおよびクリープ疲労試験結果

95MPa，105MPa での破断時間は，1322 時間および 689 時間であった. 中断試験において得られたクリープ曲線は, 同一応力条件下においてもばらつきを生じる結果となった. これは，同一応力であってもそれぞれの試験で破断時間が 異なることを示唆しており, 破断時間分数比としてのクリ ープ損傷率が明確でないことから，前述したように破断試 験片のクリープ破断ひずみに対する中断材のクリープひず みの割合をクリープ損傷率と定義することとした.

ひずみ制御疲労およびクリープ疲労試験における最大引 張および圧縮応力の繰返し数に伴う変化を Fig.1 に, 全ひ ずみ範囲と破損繰返し数の関係を Fig. 2 に示す. 本 Ni 基合 金は, 緩やかな繰返し硬化挙動を呈し, 最大引張応力がほ ぼ一定值となった後に最大引張応力が低下して破損に至っ ている. 繰返し硬化挙動には，保持時間の顕著な影響はみ られない。これより求まる破損寿命は, ひず夕保持のない 疲労試験に対し，1 時間の引張ひずみ保持を導入すること により $1 / 5$ 以下に寿命が低下している（図中○印）。ひず み範囲 $0.7 \%$ の $1 \mathrm{~h}$ ひずみ保持の破損寿命が，360 回であっ たのに対し，5h および $24 \mathrm{~h}$ 保持の破損寿命は，266回およ び 262 回となり，保持時間の増加に伴い破損寿命は短くな る傾向はあるが，その差異はわずかである，全ひずみ範囲 $0.7 \%$ の疲労およびクリープ疲労試験における寿命中期の

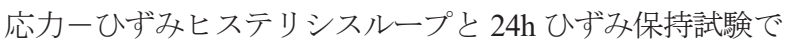
の応力緩和挙動を Fig.3 および Fig.4 に示す. ひずみ保持の ある試験のヒステリシスループに顕著な差異はみられない. 応力緩和挙動は, 保持時間による明らかな違いはなく, 保 持開始後の $250 \mathrm{MPa}$ 程度から $60 \mathrm{MPa}$ 程度まで急激な応力緩 和を生じるが，1 時間保持以降は極めて緩やかに緩和し，5 時間以降ではほとんど応力の低下はみられず $50 \mathrm{MPa}$ 程度 でほぼ一定の応力を保っている。本ニッケル基合金の 


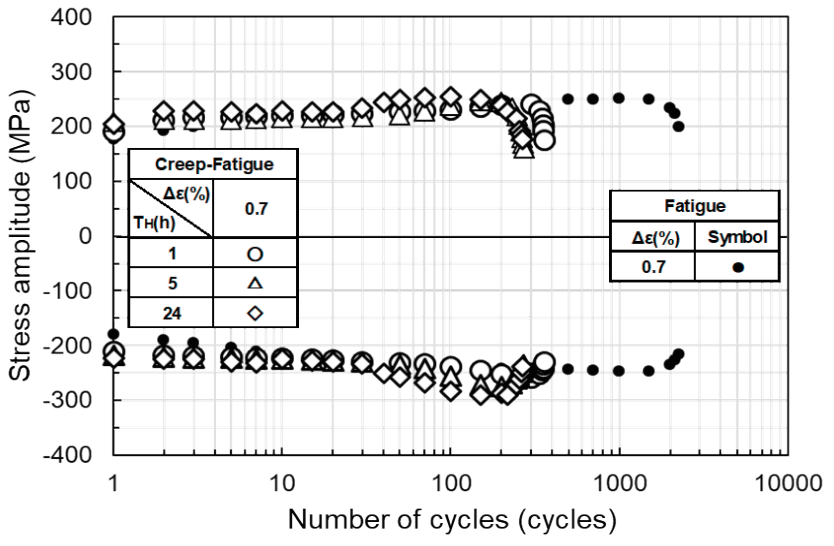

Fig.1 Comparison of peak stress amplitude with number of cycles between different strain hold times.

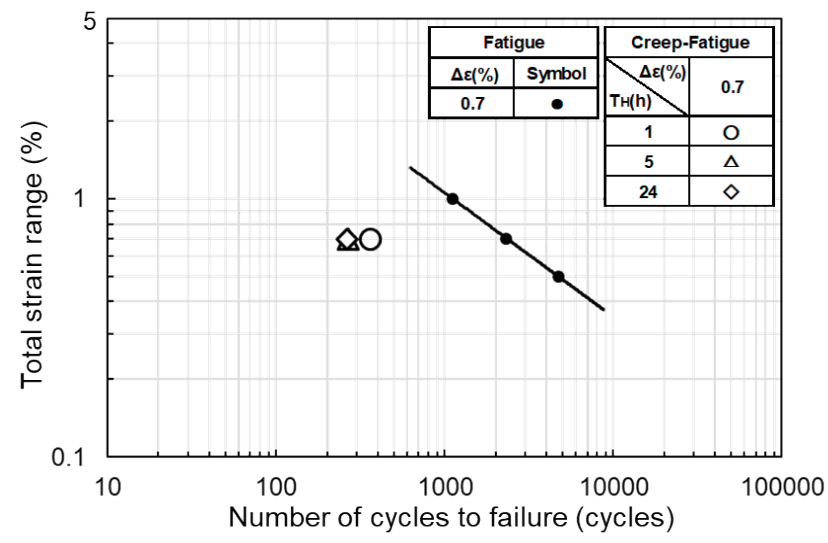

Fig.2 Relationship between total strain range and number of cycles to failure.

$50 \mathrm{MPa}$ 程度でのクリープ破断時間は, 約 60 万時間であり, 保持中のクリープ損傷が極めて小さいことからひずみ保持 時間が長くなっても寿命に及ぼす影響が表れなかったもの と考えられる。ささら長時間の保持を導入しても，保持中 の応力は $50 \mathrm{MPa}$ 以下となり, 寿命に与えるクリープ損傷は 軽微であると判断されるため，寿命低下に及ぼす影響は表 れにくいと推察される.

疲労およびクリープ, クリープ疲労条件下で破断した試 験片の破面の代表例を Fig.5 に示寸。疲労条件下で破断し た試験片の破面は，明瞭なストライエーションが観察され る粒内破壊であるが，クリープおよびクリープ疲労試験で は，すべてにおいて粒界ファセットがみられる粒界破壊を 呈しており，クリープ疲労試験ではひずみ保持中に粒界損 傷を受けたことが示唆された。また，疲労およびクリープ 試験片には，破断部以外に表面から発生したき裂は観察さ れなかったが，クリープ疲労試験片では表面から発生・成 長したき裂が観察された.

\section{2 損傷中断試験片の観察結果}

損傷中断材の試験片内部に観察されたボイドおよび微小 き裂の代表例を Fig.6 に示す。クリープおよびクリープ疲 労条件ともに，損傷 $20 \%$ 程度で粒界上に数 $\mu \mathrm{m}$ のボイドの 発生が確認された. 平均結晶粒径が約 $260 \mu \mathrm{m}$ とこれまでに ボイド観察を行ったフェライト系合金鋼 10)に比べ大きいこ

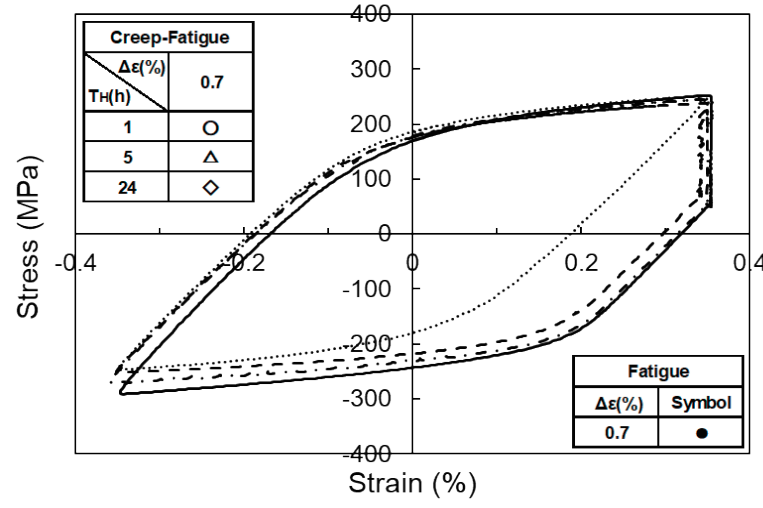

Fig.3 Comparison of stress-strain hysteresis loops at mid-failure life between different strain hold times.

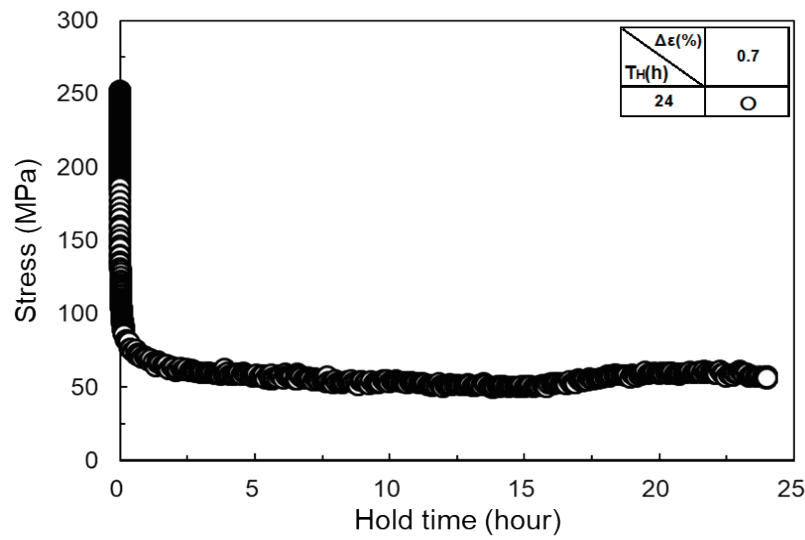

Fig.4 Stress relaxation curve obtained by 24 hours strain hold at mid-failure life.

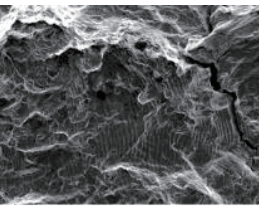

(A) Fatigue, $0.7 \%$

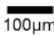

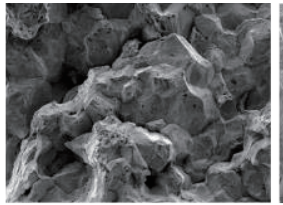

(B) Creep, 105MPa

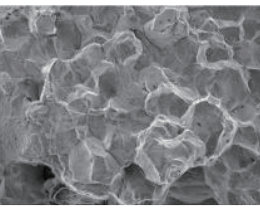

(C) Creep-fatigue, $5 \mathrm{~h}$ hold
Fig.5 Comparison of fracture surface observation results by SEM.

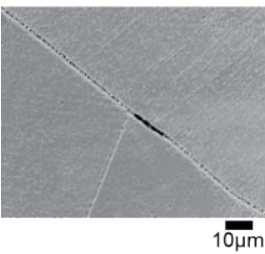

(a) $22 \%$

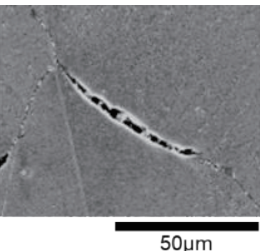

(b) $44 \%$

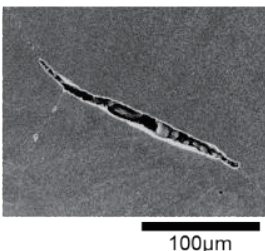

(c) $83 \%$
(A) Creep, $105 \mathrm{MPa}$

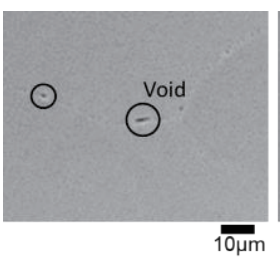

(a) $25 \%$

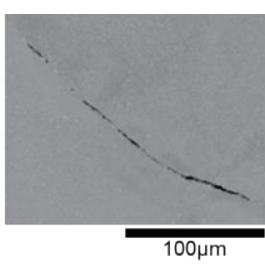

(b) $50 \%$

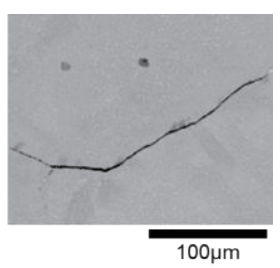

(c) $75 \%$
(B) Creep-fatigue, $5 \mathrm{~h}$ hold

Fig.6 Observation of voids and microcracks on grain boundaries in damage materials. 


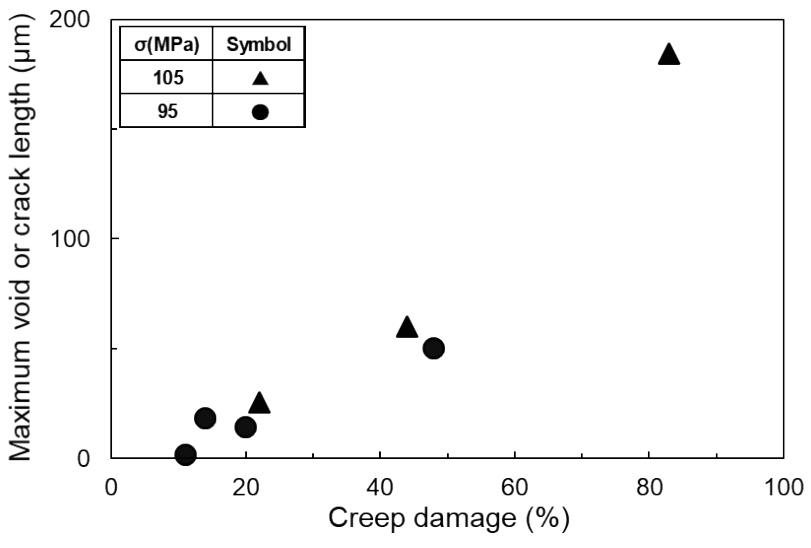

(a) Creep

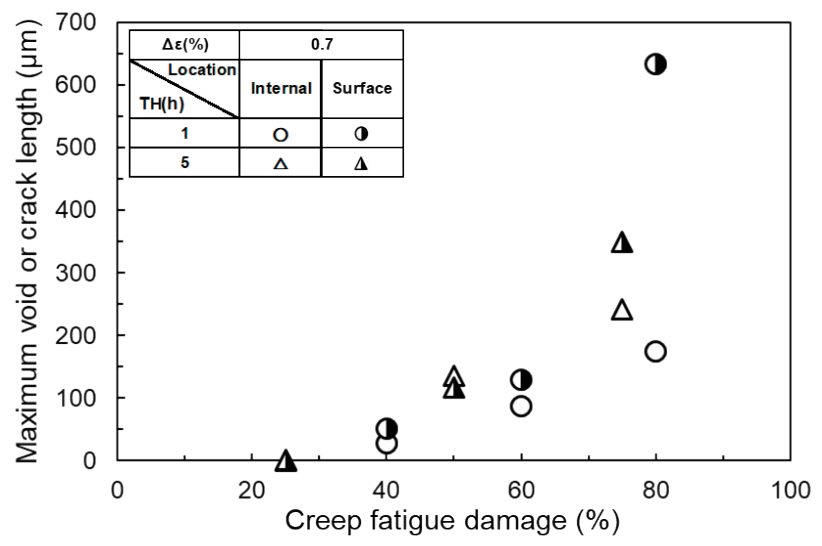

(b) Creep fatigue

Fig.7 Relationship between the maximum void or micro crack length observed at internal and surface of the damaged materials.

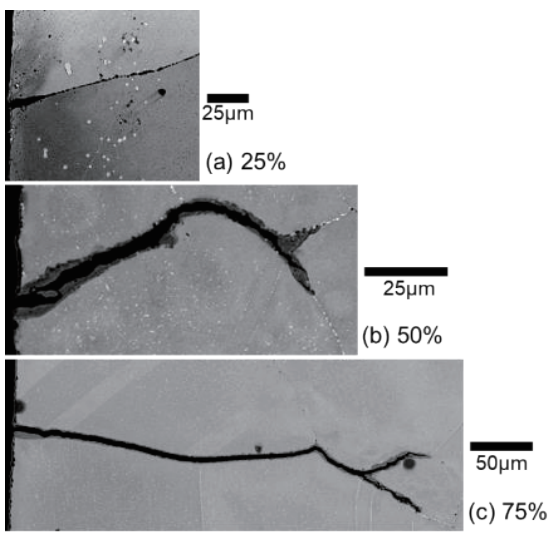

Fig.8 Crack initiation and propagation from specimen surface in 5 hour strain hold creep-fatigue test specimen.

とから，ボイド個数密度は数個 $\left(1 / \mathrm{mm}^{2}\right)$ とわずかであった. 損傷率 $50 \%$ に達すると粒界上に最大で数十 $\mu \mathrm{m}$ に成長した 微小き裂が観察され，損傷率 75\%を超えると 1 結晶粒長さ に近い $200 \mu \mathrm{m}$ を超えるような微小き裂が観察された. 観察 結果を最大ボイドおよび微小き裂長さと損傷率の関係でプ ロットしたものを Fig.7 に示す. クリープおよびクリープ 疲労条件ともに寿命初期にボイドが発生し，損傷が増すと ともに長さが増大している. フェライト系合金 ${ }^{10)}$ と比較す ると，損傷率に対するボイド発生時期は大きくは異ならな いが，50\%程度以上では最大長さが大きく，ボイドおよび 微小き裂の成長速度が速い傾向にある.

$5 \mathrm{~h}$ ひずみ保持クリープ疲労中断試験片の試験片表面で 観察されたき裂の代表例を Fig.8 に示す. なお, クリープ条 件下の中断試験片では表面き裂は観察されなかった。試験 片内部でボイド，微小き裂が発生・成長していたが，クリー プ疲労条件下では寿命初期に表面からも微小き裂が発生し （Fig.8(a)参照），これらが試験片内部のボイドや微小き裂 が発生した粒界上を進展していた (Fig.8(b)および(c)参照). き裂内部には酸化膜が生成しているが，フェライト系合金 鋼に比べるとき裂開口量自体が小さく, 酸化膜の生成も顕 著でないことは，本鋼が而埌性に優れていることを示唆し ている. 表面き裂の長さと損傷率の関係を Fig.7(b)に併せて
示している. 両保持時間の試験において同様な傾向を示し ており，20\%程度で発生した微小き裂が徐々に進展し，試 験片内部で観察された微小き裂と同様な傾向で増大してい るが，80\%を超えると加速的に進展した様子が伺える．こ のような観察結果から, クリープ疲労条件下では, 表面近 傍と内部で同様のメカニズムにより粒界でクリープ損傷が 進行したこと、寿命末期において表面からのき裂が内部の 損傷を受けた粒界を成長することにより, 疲労条件下に比 べ寿命が低下したものと考えられる．24h 保持試験の破損 試験片の破損部以外の表面で観察されたき裂の長さが，1h および $5 \mathrm{~h}$ 保持の破損試験片で観察されたき裂と同等であ ったことから，24h 保持においても同様な傾向で表面き裂 が進展したものと推察される.

3.3 クリープ疲労寿命評価

本研究で実施した長時間引張ひずみ保持条件に対する既 存のクリープ疲労寿命評価法の適用性を検討するため, 設 計基準にも採用されている線形損傷則である時間消費則と 延性消耗則による寿命評価を行う。両損傷則において疲労 損傷は, 次式で与えられる.

$D_{f}=N / N_{f}$

ここで，Nはクリープ疲労における繰返し数， $N_{f}$ はクリ ープ疲労と同一ひずみ範囲における疲労寿命である.

応力基準である時間消費則では，クリープ損傷は以下 の式で表される.

$D_{c}=N \int_{0}^{t} d t / t_{r}$

ここで, $t$ は保持時間, $t_{r}$ は任意の応力でのクリープ破断 時間である。また，ひずみ基準である延性消耗則では， クリープ損傷 $D_{c}$ は以下の式で表される.

$D_{c}=N \frac{\Delta \varepsilon_{c}}{\varepsilon_{d}}$ 


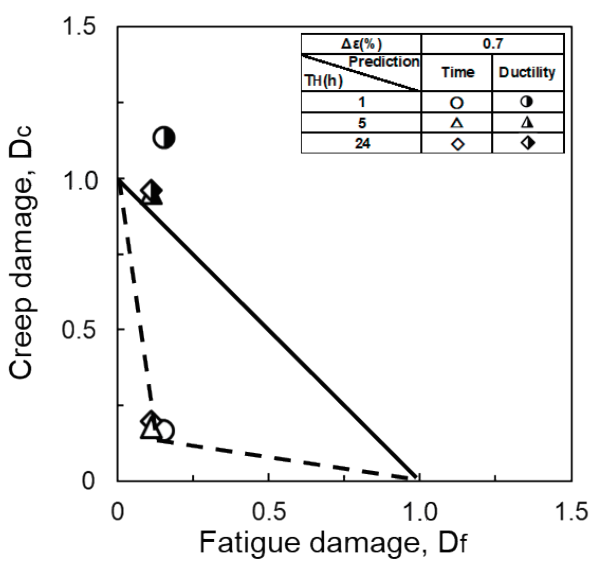

(a) Dc-Df

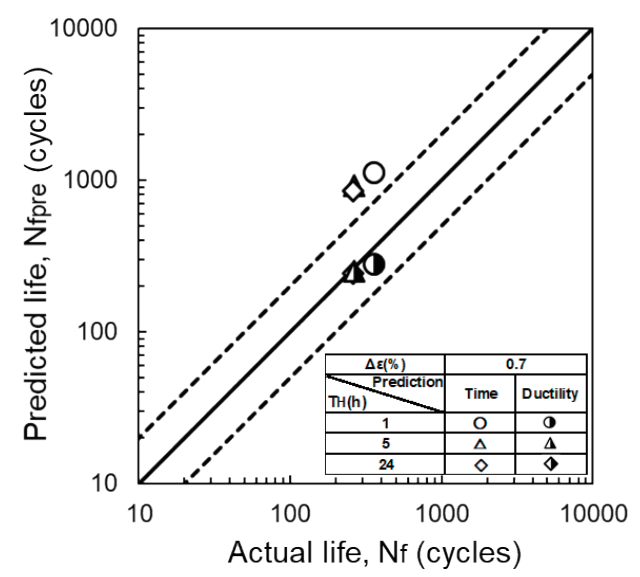

(b) Nf-Nfpre

Fig.9 Creep and fatigue damage diagram, and life prediction results obtained by two different damage rules.

ここで, $\Delta \varepsilon_{c}$ は保持中の累積クリープひずみ, $\varepsilon_{d}$ はクリー プ破断延性である. $\mathrm{HR} 6 \mathrm{~W}$ の真破断延性は，クリープ試 験結果より 0.3 とした。破損寿命は, $\mathrm{D}=1$ を破損のクラ イテリオンとして予測した.

両損傷則で評価したクリープおよび疲労損傷の関係 をFig.9(a)に，予測された破損寿命と実験值を比較して， Fig.9(b)に示す．時間消費則では，ひずみ保持時間による 傾向の差異は認められず，予測寿命が実験值より長く, 損傷を過小評価した。これは, Fig.9(a)からわかるように， 本 $\mathrm{Ni}$ 基合金に対しては線形和が $\mathrm{D}=1$ より小さいためで ある. ASME 設計基準で採用されているフェライト系合 金の損傷值 $((\mathrm{Dc}, \mathrm{Df})=(0.15,0.15))$ を通る 2 直線（図中の破 線）を採用することにより，実験值に近い予測が可能と なる。一方，延性消耗則では予測結果が実験值と概ね一 致しており，本研究の範囲内では良好な予測を与える結 果となった。ただし，延性消耗則は，フェライト系合金 鋼に対してみられたように，同一保持時間であってもク リープ損傷が全ひずみ範囲依存する傾向（ひずみ範囲が 小さいほどクリープ損傷が大きくなる）が認められてい

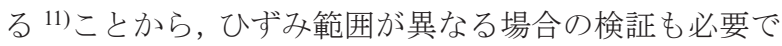
ある。

\section{EBSD による結晶方位解析結果および考察}

これまでに EBSDによる結晶方位解析結果と損傷との 間に相関関係がみられることから，EBSD による結晶方 位解析の非破壊損傷評価への適用が期待されている。こ れまでには，改良 9Cr 鋼 4)やSUS304 鋼 5)のクリープ損 傷の増大に伴い局所方位差(KAM)が大きくなること，Ni 基超合金に対しては応力制御下のクリープ疲労条件に おいて，損傷の進行に伴って KAM 值が増大することな どが報告されている ${ }^{8)}$. しかしながら， Ni 基合金のクリ 一プおよびひずみ制御クリープ疲労条件下における損 傷の進行と結晶方位差変化の関係については明らかに されていない.ここでは，HR6W のクリープおよびひず み制御クリープ疲労条件下の損傷と結晶方位差変化の 関係を調べた。

局所方位差の分布を示す KAM マップの損傷に伴う変化 の代表例としてクリープ (負荷応力 $105 \mathrm{MPa}$ ) およびクリー プ疲労 (5h ひずみ保持) 条件下の結果を Fig.10に示す. 同 図では, $0^{\circ} \sim 5^{\circ}$ 範囲の KAM 值を色別で示している. 未 損傷材では，ほぼ全体が青色であり，方位差が 1 ○以内であ るが，損傷の進行に伴って粒界近傍で緑色が少しずつ増加 している. 変形が進行するクリープ条件下では, 粒界に発 生したき裂が明膫に観察され，き裂近傍で KAM 值が大き い箇所もみられることから，結晶粒界近傍でのひずみ集中 がボイドの発生，成長を促進した可能性も伺われる，クリ 一プ疲労条件においても損傷の進行に伴い粒界近傍で緑色 にみえる KAM 值が大きい箇所が増加している. 疲労試験 および $24 \mathrm{~h}$ ひずみ保持試験で破損した試験片の KAM マッ プを比較すると, 疲労試験で破損した試験片は, ほぼ全体 が青色であり，局所領域における KAM 值の増大はみられ ないが，24h 保持試験では，5h 保持試験同様に粒界近傍の 局所領域に方位差の大きい箇所がみられた.このことから， 引張および圧縮ひずみが対称に負荷される疲労試験では, 損傷が増大しても KAM 值の変化としては表れないが，非 対称ひずみ波形であるクリープ疲労条件の場合には KAM 值が増大寸ることがわかる。

これまでも損傷との関係を調べる中で用いられている, これらのマップにおける KAM の平均值 $\left(\mathrm{KAM}_{\mathrm{ave}}\right)$ と損傷と の関係を Fig.11(a)に示す. なお，縦軸は未損傷材で基準化 した值をとっている. 基準化 $\mathrm{KAM}_{\mathrm{ave}}$ は，クリープおよび クリープ疲労条件で同様に, 損傷の増大とともにほぼ単調 に増加しており，損傷との相関が認められる．KAMave は， マップ全体の KAM 值の平均值として算出されるが, Fig.10 の KAM マップからわかるように，KAM 值は粒界近傍の 局所領域において顕著に増加していることから，それをよ り明確にとらえるためには粒内全体の平均ではなく粒界近 傍の局所領域の変化を顕在化させるほうがよいと考えられ る. そこで，マップにおける KAM 值の計測データ（結晶 方位分布）において, 上位 $10 \%$ までの $\mathrm{KAM}$ の平均值 

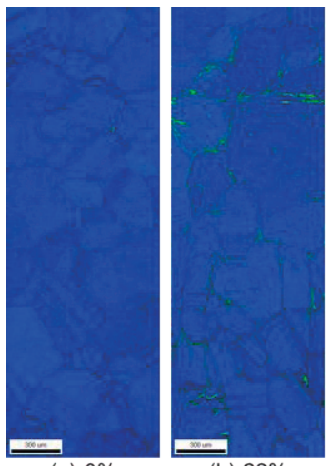

(b) $22 \%$

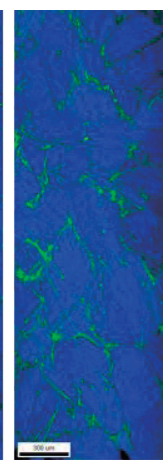

(c) $44 \%$

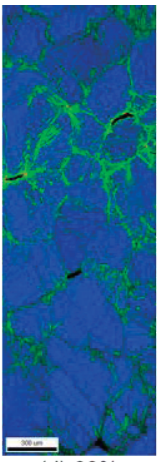

(d) $83 \%$

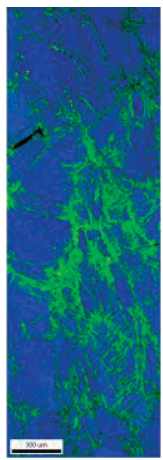

(e) $100 \%$ $300 \mu \mathrm{m} \sum_{0}$

(A) Creep, 105MPa

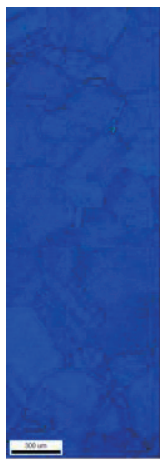

(a) $0 \%$

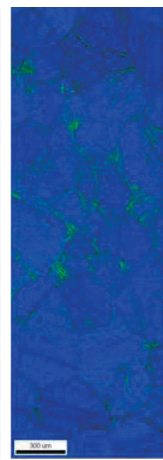

(b) $25 \%$

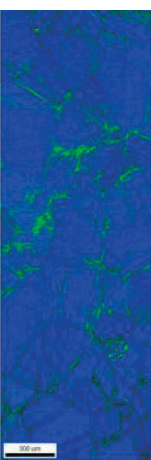

(c) $50 \%$

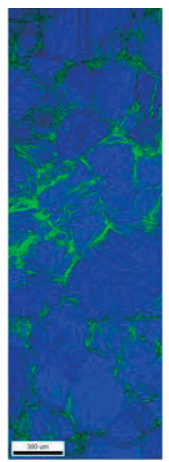

(d) $75 \%$

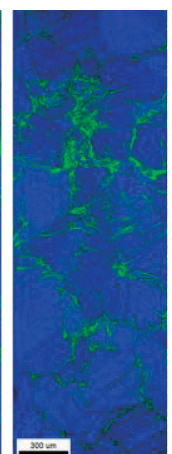

(e) $100 \%$ $500 \mu \mathrm{m}$
(B) Creep-fatigue, $5 \mathrm{~h}$ hold

Fig.10 Change in KAM map with creep and creep fatigue damage.

$\left(\mathrm{KAM}_{10 \%}\right)$ を求めることとした。 $\mathrm{KAM}_{10 \%}$ と損傷の関係を Fig.11(b)に示寸. 縦軸は, 未損傷材の $\mathrm{KAM}_{10 \%}$ で基準化して いる. 基準化 $\mathrm{KAM}_{10 \%}$ は，クリープおよびクリープ疲労で 同様に損傷の進行とともにほぼ単調に増加している．損傷 に対する増加率は基準化 $\mathrm{KAM}_{\mathrm{ave}}$ に比べ大きいことから， 損傷を評価する非破壊損傷パラメータとしては有効である。 以上の上うに，一定荷重下で変形が進行するクリープ条件 とひずみ制御下で変形が一定のクリープ度労条件下での損 傷に伴う KAM 值の変化に差異を生じないことが明らかと なった，クリープ条件下では，時間の経過により粒内全体 で変形が進行するとともに，隣接する結晶粒との方位差に より粒界近傍の局所領域に転位が集積寸るものと考えられ る。一方，クリープ疲労条件下では，引張負荷過程で塑性 変形により粒界近傍に転位が集積した後, 引張保持中に弹 性ひずみが減少し，クリープひずみが増大することによっ て転位のさらなる集積により，圧縮過程において逆方向に 移動せず残留した転位が，非可逆的に蓄積するものと考え られる ${ }^{12)}$. 粒界近傍への転位集積のメカニズムは異なるも のの, 結晶方位の変化は転位の蓄積に対応して生じるとみ なせることから，粒界近傍の局所領域に限ると，クリープ およびクリープ疲労条件において KAM 值の増加に顕著な 差異を生じなかったものと解釈される、ひずみ範囲が異な る場合については明らかでないが，本研究の範囲内では，

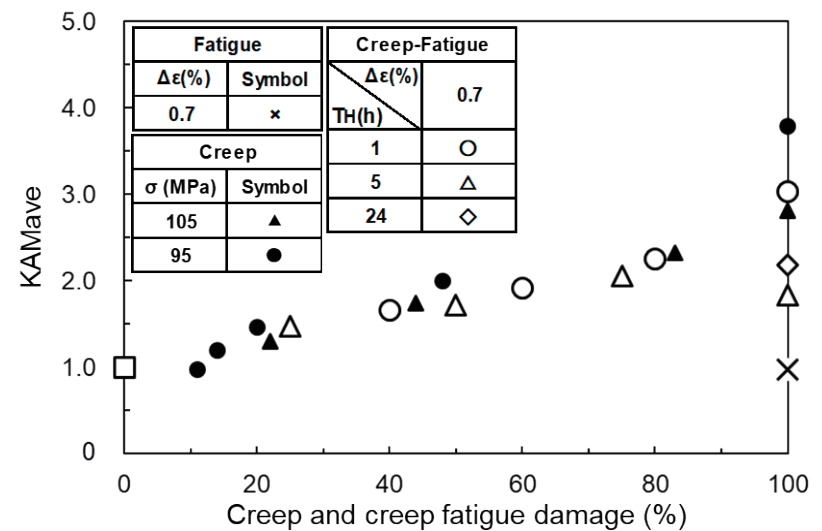

(a) KAMave

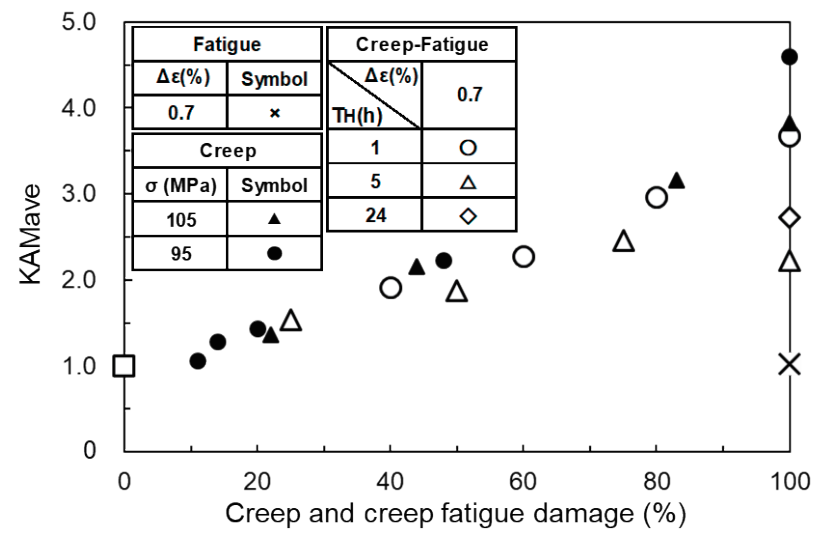

(b) KAM10\%

Fig.11 Relationship between $\mathrm{KAM}_{\text {ave }}$ and creep and creep fatigue damage.

クリープおよびクリープ疲労条件下の損傷を， $\mathrm{KAM}_{10 \%}$ を 計測することにより推定できる可能性が示された。 また, 試験片の表面近傍においても KAM 值の計測を行い，損傷 との関係を調べたが，基準化した $\mathrm{KAM}_{\mathrm{ave}} ， \mathrm{KAM}_{10 \%}$ の損傷 に伴う変化は，Fig.11 とほぼ同等であり，内部との差異は みられなかった。

KAM は，その定義から粒内の局所領域の結晶方位差を 示寸のに対し, GROD は結晶粒内全体の平均方位からの偏 差を示寸とみなせる.クリープおよびクリープ疲労損傷材 に対して計測された GROD マップの代表例を Fig.12 に示 寸. 同図では, $0^{\circ} \sim 30^{\circ}$ の範囲の GROD 值を色別で示して いる. クリープ条件下の GROD マップの損傷に伴う変化は, KAM マップとは異なり, 結晶粒内の広い領域で緑色の GROD の高いところが夕られ，損傷の進行に伴って緑色の 領域が広がっている。これは，クリープ変形の進行により 結晶粒内全体的にひずみが増加するが, 結晶粒ごとに蓄積 するひずみが異なることを示唆している. 別途取得した逆 極点図（IPF マップ）と対応させると, GROD の高い領域 は(001)に近い方位の結晶粒と, 低い領域は(101)に近い方位 の結晶粒と対応する部分が多いようである。一方，クリー プ度労損傷材の GROD マップでは, 損傷の進行に伴って粒 界近傍における GROD 值が上昇する傾向があり,クリープ 損傷材と異なり粒内の広い領域で GROD 值が高くなる様 子はみられない。このように，クリープ条件下では，クリ 


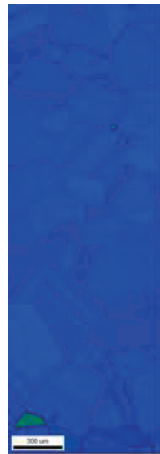

(a) $0 \%$

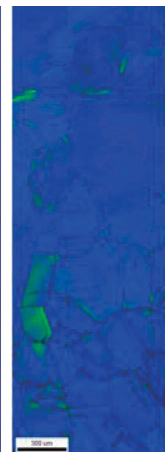

(b) $22 \%$

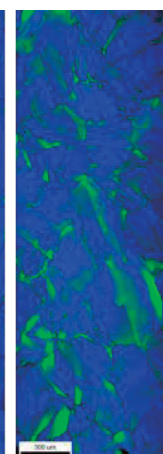

(c) $44 \%$

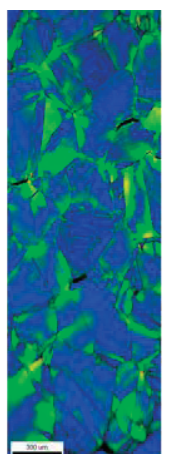

(d) $83 \%$

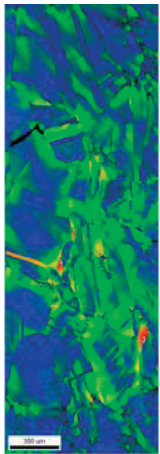

(e) $100 \%$ $\frac{\text { e) } 100 \%}{300 \mu \mathrm{m}}$
(A) Creep, $105 \mathrm{MPa}$

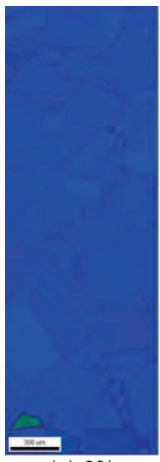

(a) $0 \%$

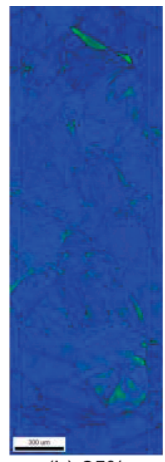

(b) $25 \%$

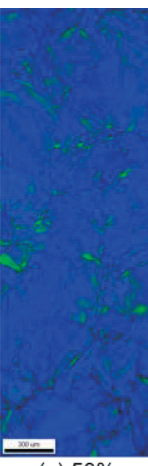

(c) $50 \%$

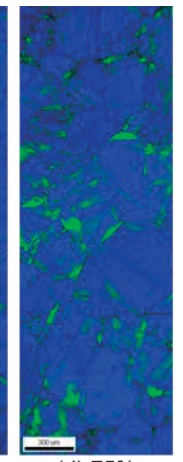

(d) $75 \%$

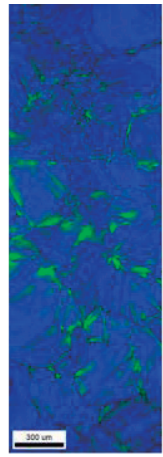

(e) $100 \%$ $300 \mu \mathrm{m} \prod_{0}$

(B) Creep-fatigue, $5 \mathrm{~h}$ hold

Fig.12 Change in GROD map with creep and creep fatigue damage.

ープ変形の進行に伴って粒内のひずみが増大することによ

り GROD 值が粒内で全体的に高くなるが，クリープ疲労条 件下では, ひずみが一定であるため粒内での GROD 值の変 化は小さく，粒界近傍でひずみが蓄積することにより GROD 值が上昇しており，負荷条件での差異が明確に表れ た.この傾向は， 1 結晶粒内の GROD ラインプロファイル からも確認された。

GROD マップから得られる GROD の平均值 GRODave と 損傷の関係を Fig.13 に示す．縦軸は，未損傷材の值で基準 化しており, 図中には疲労試験および 24 時間保持クリープ 疲労試験の破損試験片の計測值も示している.クリープ条 件とクリープ疲労条件ともに GRODave は損傷に伴って単調 に増加しているが，増加率は変形の進行を伴うクリープ条 件下で大きくなっている. クリープ条件下での基準化 $\mathrm{GROD}_{\mathrm{ave}}$ の変化が応力に依存していないことから，クリー プひずみの増加に対応しているとみなすことができる。ま た，巨視的な変形が一定のひずみ制御クリープ疲労条件で あっても，引張ひずみ保持を伴うことにより粒内のひずみ 分布に変化を生じ，粒内結晶方位の平均值からの偏差が繰 返しとともに増大するものと考えられる. 本試験範囲では, ひずみ保持時間に依存せず同様な増加傾向を示した。 GROD 值の損傷に伴う変化は，負荷ひずみ範囲に依存する 可能性もあり，今後明らかにする必要がある.

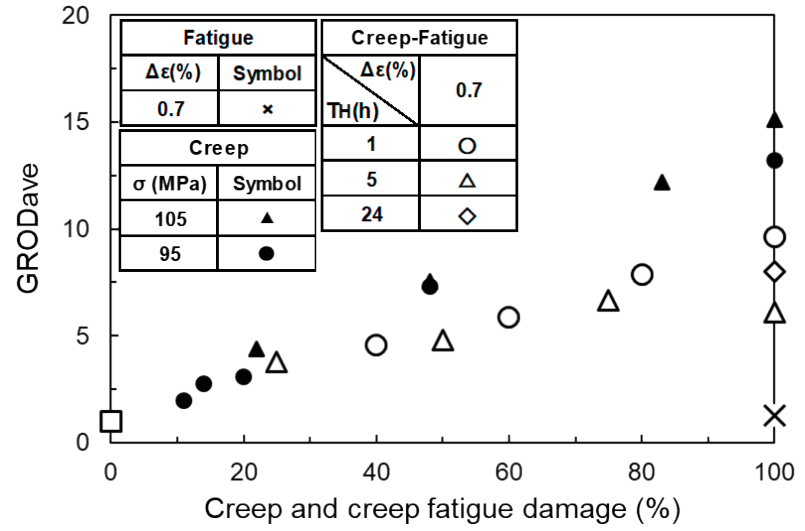

Fig.13 Relationship between GROD $_{\text {ave }}$ and creep and creep fatigue damage.

\section{5 結言}

ニッケル基合金 HR6W を対象にクリープおよび長時間 ひずみ保持クリープ疲労試験を実施し，損傷過程を明らか にするとともに，EBSD 法による結晶方位差測定を行い， 方位差と損傷との関係を調べた，得られた結果を以下に要 約する.

(1) 保持のない疲労条件下に比べ, 1 時間のひずみ保持 を導入することにより $1 / 5$ 程度に破損寿命が低下し た. 保持時間の増加に伴って低下度合が大きくなる 傾向はあったが， 5 時間および 24 時間で顕著な差 異は生じなかった。

(2) クリープおよびクリープ疲労条件下において, 損傷 率 $20 \%$ 程度で粒界上に数 $\mu \mathrm{m}$ のボイドの発生が, $50 \%$ 程度に達すると粒界上に最大で数十 $\mu \mathrm{m}$ に成長 した微小き裂が，損傷率 $75 \%$ を超えると 1 結晶粒 長さに近い $200 \mu \mathrm{m}$ を超えるき裂が観察された。 ク リープ疲労条件下では, 外表面からもき裂が発生し ており,その成長過程は内部で観察されたき裂と同 様な傾向を示した。

(3) 局所方位差を示す KAM マップから，クリープ，ク リープ疲労条件ともに, 損傷が増大するに伴って粒 界近傍で KAM 值が上昇した. 初期值で基準化した $\mathrm{KAM}$ の粒内全体の平均值および上位 $10 \% \mathrm{KAM} の$ 平均值は，損傷とともに単調に増大寸ることから， これらを計測することにより,クリープおよびクリ ープ疲労損傷が検出できる可能性が示唆された.

(4) 結晶粒の平均方位差からの偏差を示す GROD マッ プは, クリープ条件下では損傷とともに粒内全体で 值が上昇する傾向が, クリープ疲労条件下では粒界 近傍で上昇する傾向がみられ, 負荷形態による差異 を生じた．損傷の増大に伴って GROD の平均值も 増大寸るが, 粒内変形を伴うクリープ条件下でその 割合が大きいことが明らかとなった。

試験片作製および試験実施にあたっては，(株）神戸工 業試験場にご協力いただいた。また，本研究の遂行にあ たり私立大学戦略的研究基盤形成支援事業 S1511002 の 
助成を受けた。これらを記して感謝の意を表する.

\section{参 考 文 献}

1) N. Saito, N. Komai, Y. Sumiyoshi, Y. Takei, M. Kitamura and T. Tokairin, "Materials development for A-USC boiler”,Mitsubishijuko giho, Vol.52, No.4, pp.27-35(2015).

2) H. Semba, H. Okada, T. Hamaguchi, S. Ishikawa and M. Yoshizawa, "Development of boiler tubes and pipes for advanced USC power plants", Shinnittetsusumikin giho, Vol.397, No.4, pp.7177(2013).

3) Y. Noguchi, M. Miyahara, H. Okada, M. Igarashi and K. Ogawa, "Creep-fatigue properties of $\mathrm{Fe}-\mathrm{Ni}$ base alloy $\mathrm{HR} 6 \mathrm{~W}$ for piping in $700^{\circ} \mathrm{C}$ USC power plants", Journal of the Society of Materials Science, Japan, Vol.57, No.6, pp.569-575(2008).

4) K. Fujiyama, A. Ogawa, K. Harada and H. Kimachi, "EBSD analysis of grain strain distribution for creep damaged modified 9Cr steel", Journal of the Society of Materials Science, Japan, Vol.64, No.2, pp.9499(2015).

5) K. Kubushiro, Y. Sakakibara and T. Ohtani, “Creep strain analysis of austenitic stainless steel by SEM/EBSD", Journal of the Society of Materials Science, Japan, Vol.64, No.2, pp.106-112(2015).

6) R. Yoda, M. Kamaya, H. Kimura, T. Ohtani and K. Fujiyama, "Round robin test using EBSD for creep damage evaluation", Journal of the Society of Materials Science, Japan, Vol.66, No.2, pp.130137(2017).

7) R. Takaku, D. Saito and Y. Yoshioka, "Effect of grain size and crystal orientation on creep damage evaluation by changes of misorientation in Hastelloy X", Journal of the Society of Materials Science, Japan, Vol.58, No.3, pp.229-234(2009).

8) D. Kobayashi, T. Takeuchi, K. Nakabeppu and T. Yokobori, "Creep damage assessment of notched material made of a solidification control $\mathrm{Ni}$-base superalloy using the EBSD method", Journal of the Society of Materials Science, Japan, Vol.67, No.2, pp.276-283(2018).

9) T. Ohtani, "Misorientation analysis by electron backscatter diffraction(EBSD) for material", Journal of the Society of Materials Science, Japan, Vol.66, No.11, pp.861-867(2017).

10) T. Ogata, "Influence of cyclic loading on creep void growth in CrMoV forging steel", Journal of the Society of Materials Science, Japan, Vol.66, No.1, pp.43-50(2017).

11) T. Ogata and A. Nitta, "Creep-fatigue life evaluation for boiler and turbine materials by applying the modified damage rate approach", Denryokuchuokenkyujo houkoku, T92057(1993).

12) T. Ogata, M. Arai and A. Nitta, "Clarification of creep-fatigue damage mechanism of high temperature structural materials (I)", Denryokuchuokenkyujo houkoku T93018(1994). 